\title{
Front Matter: Volume 10788
}

, "Front Matter: Volume 10788," Proc. SPIE 10788, Active and Passive Microwave Remote Sensing for Environmental Monitoring II, 1078801 (30 November 2018); doi: 10.1117/12.2519761

SPIE. Event: SPIE Remote Sensing, 2018, Berlin, Germany 


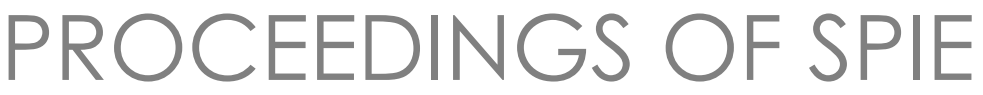

\title{
Active and Passive Microwave Remote Sensing for Environmental Monitoring II
}

\author{
Fabio Bovenga \\ Claudia Notarnicola \\ Nazzareno Pierdicca \\ Emanuele Santi \\ Editors
}

12-13 September 2018

Berlin, Germany

Sponsored by

SPIE

Cooperating Organisations

European Optical Society

European Association of Remote Sensing Companies (Belgium)

CENSIS - Innovation Centre for Sensor and Imaging Systems (United Kingdom)

ISPRS - International Society for Photogrammetry and Remote Sensing

EARSeL-European Association of Remote Sensing Laboratories (Germany)

Remote Sensing \& Photogrammetry Society (United Kingdom)

Published by

SPIE

Volume 10788 
The papers in this volume were part of the technical conference cited on the cover and title page. Papers were selected and subject to review by the editors and conference program committee. Some conference presentations may not be available for publication. Additional papers and presentation recordings may be available online in the SPIE Digital Library at SPIEDigitalLibrary.org.

The papers reflect the work and thoughts of the authors and are published herein as submitted. The publisher is not responsible for the validity of the information or for any outcomes resulting from reliance thereon.

Please use the following format to cite material from these proceedings:

Author(s), "Title of Paper," in Active and Passive Microwave Remote Sensing for Environmental Monitoring II, edited by Fabio Bovenga, Claudia Notarnicola, Nazzareno Pierdicca, Emanuele Santi, Proceedings of SPIE Vol. 10788 (SPIE, Bellingham, WA, 2018) Seven-digit Article CID Number.

ISSN: 0277-786X

ISSN: 1996-756X (electronic)

ISBN: 9781510621596

ISBN: 9781510621602 (electronic)

Published by

SPIE

P.O. Box 10, Bellingham, Washington 98227-0010 USA

Telephone +1360 676 3290 (Pacific Time) · Fax +1 3606471445

SPIE.org

Copyright @ 2018, Society of Photo-Optical Instrumentation Engineers.

Copying of material in this book for internal or personal use, or for the internal or personal use of specific clients, beyond the fair use provisions granted by the U.S. Copyright Law is authorized by SPIE subject to payment of copying fees. The Transactional Reporting Service base fee for this volume is $\$ 18.00$ per article (or portion thereof), which should be paid directly to the Copyright Clearance Center (CCC), 222 Rosewood Drive, Danvers, MA 01923. Payment may also be made electronically through CCC Online at copyright.com. Other copying for republication, resale, advertising or promotion, or any form of systematic or multiple reproduction of any material in this book is prohibited except with permission in writing from the publisher. The CCC fee code is 0277 $786 \mathrm{X} / 18 / \$ 18.00$.

Printed in the United States of America.

Publication of record for individual papers is online in the SPIE Digital Library.

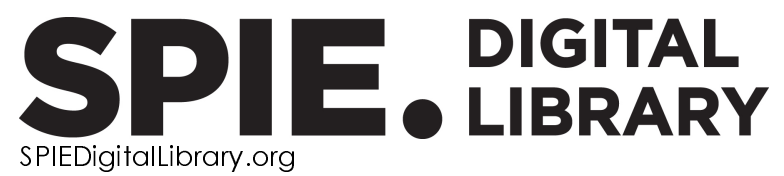

Paper Numbering: Proceedings of SPIE follow an e-First publication model. A unique citation identifier (CID) number is assigned to each article at the time of publication. Utilization of CIDs allows articles to be fully citable as soon as they are published online, and connects the same identifier to all online and print versions of the publication. SPIE uses a seven-digit CID article numbering system structured as follows:

- The first five digits correspond to the SPIE volume number.

- The last two digits indicate publication order within the volume using a Base 36 numbering system employing both numerals and letters. These two-number sets start with 00, 01, 02, 03, 04, 05, 06, 07, 08, 09, OA, OB ... 0Z, followed by 10-1Z, 20-2Z, etc. The CID Number appears on each page of the manuscript. 


\title{
Contents
}

\author{
$\checkmark \quad$ Authors \\ vii Conference Committee
}

SESSION JS1 JOINT SESSION WITH VOLUME 10789: SAR DATA PROCESSING I

1078803 Influence of preprocessing of radar images on neural network recognition accuracy [10788-21]

SESSION JS2 JOINT SESSION WITH VOLUME 10789: SAR DATA PROCESSING II

1078805 Land cover classification using integrated optical and SAR data in comparison of speckle noise effect: a case study in Hong Kong Wetland Park [10788-23]

SESSION $1 \quad$ MW APPLICATIONS I

1078806 Using passive microwave data to understand spatio-temporal trends and dynamics in snowwater storage in High Mountain Asia [10788-1]

1078809 Potential of UAV GNSS-R for forest biomass mapping [10788-4]

SESSION 2 INSAR APPLICATIONS AND TECHNIQUES I

10788 OB Performance evaluation of a new MMW Arc SAR system for underground deformation monitoring [10788-6]

\section{SESSION $3 \quad$ MW APPLICATIONS II}

$10788 \mathrm{OE}$ Effects of atmospheric precipitations and turbulence on satellite Ka-band synthetic aperture radar [10788-10]

10788 OF Incorporating Sentinel-derived products into numerical weather models: the ESA STEAM project [10788-11]

10788 OG Insights into burned areas detection from Sentinel-1 data and locally adaptive algorithms (Best Student Paper Award) [10788-12] 
$10788 \mathrm{OH} \quad$ Exploitation of SAR data to detect burned areas in the Sila mountain area (southern Italy) [10788-13]

10788 Ol Capability of decomposition methods for identification of crops and other land-cover targets using hybrid polarimetric SAR data [10788-14]

\section{SESSION 4 INSAR APPLICATIONS AND TECHNIQUES II}

10788 OK Analysis of the 2018 Hualien earthquake (Taiwan) by using SAR interferometry and pixel offset techniques [10788-17]

10788 ON Verification of high-resolution and precision TEC retrieval based on the PALSAR full-polarimetric data [10788-19]

\section{POSTER SESSION}

10788 OP Landslide detection using polarimetric ALOS-2/PALSAR-2 data: a case study of 2016 Kumamoto earthquake in Japan [10788-25]

10788 OS A cylindrical symplectic multi-resolution time-domain algorithm with perfectly matched layer [10788-28]

10788 OT Temporal backscattering coefficient decorrelation in burned areas [10788-30]

10788 OU L-band SAR sensitivity to prescribed burning effects in eucalypt forests of Western Australia [10788-31]

10788 OY Calibration and validation of small satellite passive microwave radiometers: MicroMAS-2A and TROPICS [10788-35] 


\section{Authors}

Numbers in the index correspond to the last two digits of the seven-digit citation identifier (CID) article numbering system used in Proceedings of SPIE. The first five digits reflect the volume number. Base 36 numbering is employed for the last two digits and indicates the order of articles within the volume. Numbers start with $00,01,02,03,04,05,06,07,08,09,0 A, 0 B \ldots . .0 Z$, followed by 10-12, 20-2Z, etc.

Amici, Stefania, $\mathrm{OH}$

Barindelli, Stefano, OF

Belenguer-Plomer, Miguel A., OG, OT, OU

Bignami, Christian, $\mathrm{OH}$

Biscarini, Marianna, OE

Blackwell, W., OY

Bookhagen, Bodo, 06

Borodinov, A. A., 03

Bovenga, Fabio, OK

Cahoy, Kerri, OY

Carvalhais, Nuno, 09

Cecchetti, M., OB

Chang, Chung-Pai, OK

Chen, Liang, ON

Chen, Zhongwei, OS

Chuvieco, Emilio, 0G, OT

Coppi, F., OB

Crews, Angela, oY

De, Atasi, Ol

Dente, Laura, 09

DiLiberto, Michael, OY

Ding, Xiaoli, 05

Fernandez-Carrillo, Angel, OG, OT, OU

Ferrazzoli, Paolo, 09

Gatti, Andrea, OF

Grant, Michael, OY

Guerriero, Leila, 09

Guo, Wulong, ON

Konishi, Tomohisa, OP

Kumar, Dheeraj, 0 l

Lagasio, Martina, OF

Leslie, R. Vincent, OY

Lu, Chih-Heng, OK

Marzano, Frank S., OE

Marziani, Augusto, OE

McCaw, L., OU

Milstein, Adam, OY

Mori, Saverio, OE

Myasnikov, V. V., 03

$\mathrm{Ni}$, Jiazheng, OS

Osaretin, Idahosa, oY

Parodi, Antonio, OF

Passera, Emanuele, OF

Patel, Parul, Ol

Pierdicca, Nazzareno, 09, 0E, OF

Piscini, Alessandro, $\mathrm{OH}$

Polcari, Marco, $\mathrm{OH}$

Pulvirenti, Luca, OF

Realini, Eugenio, OF
Romaniello, Vito, $\mathrm{OH}$

Rommen, Bjorn, OF

Rossi, M., OB

Silva, Pedro F., 09

Smith, Taylor, 06

Soares, Paula, 09

Stramondo, Salvatore, $\mathrm{OH}$

Suga, Yuzo, OP

Tanase, Mihai A., OG, OT, OU

Tang, Xiao, 05

Tang, Xingji, OS

Venuti, Giovanna, OF

Wang, Cheng, ON

Yen, Jiun-Yee, OK

Zhang, Lei, 05

Zhang, Li, OS

Zhao, Haisheng, ON 
Proc. of SPIE Vol. 10788 1078801-6

Downloaded From: https://www.spiedigitallibrary.org/conference-proceedings-of-spie on 25 Apr 2023 Terms of Use: https://www.spiedigitallibrary.org/terms-of-use 


\title{
Conference Committee
}

\author{
Symposium Chair
}

Christopher M. U. Neale, University of Nebraska-Lincoln

(United States) and Daugherty Water for Food Institute

(United States)

Symposium Co-chair

Karsten Schulz, Fraunhofer-Institut für Optronik, Systemtechnik und Bildauswertung (Germany)

Conference Chairs

Fabio Bovenga, CNR ISSIA (Italy)

Claudia Notarnicola, EURAC research (Italy)

Nazzareno Pierdicca, Università degli Studi di Roma La Sapienza Italy)

Emanuele Santi, Istituto di Fisica Applicata Nello Carrara (Italy)

Conference Programme Committee

Richard Bamler, Deutsches Zentrum für Luft- und Raumfahrt e.V. (Germany)

Maria-Paola Clarizia, University of Michigan (United States)

Fabio Covello, Agenzia Spaziale Italiana (Italy)

Katarzyna Dabrowska-Zielinska, Institute of Geodesy and Cartography (Poland)

Mihai P. Datcu, Deutsches Zentrum für Luft- und Raumfahrt e.V. (Germany)

Fabio Del Frate, Università degli Studi di Roma "Tor Vergata" (Italy)

Dara Entekhabi, Massachusetts Institute of Technology (United States)

Carlos Lopez-Martinez, Universitat Politècnica de Catalunya (Spain)

Simonetta Paloscia, Istituto di Fisica Applicata Nello Carrara (Italy)

Luca Pulvirenti, CIMA Research Foundation (Italy)

Stefan Schneiderbauer, EURAC research (Italy)

David Small, University of Zürich (Switzerland)

Session Chairs

JS1 Joint Session with Volume 10789: SAR Data Processing I

Lorenzo Bruzzone, Università degli Studi di Trento (Italy) 
JS2 Joint Session with Volume 10789: SAR Data Processing II

Claudia Notarnicola, EURAC research (Italy)

Lorenzo Bruzzone, Università degli Studi di Trento (Italy)

1 MW Applications I

Emanuele Santi, Istituto di Fisica Applicata Nello Carrara (Italy)

2 InSAR Applications and Techniques I

Fabio Bovenga, CNR ISSIA (Italy)

3 MW Applications II

Luca Pulvirenti, CIMA Research Foundation (Italy)

4 InSAR Applications and Techniques II

Fabio Bovenga, CNR ISSIA (Italy) 